\title{
Explaining the Evolving Web - Mixing Technology with Pleasure
}

\author{
Robert I. Benjamin ${ }^{1}$, Rolf T. Wigand ${ }^{2}$, Johanna L. H. Birkland ${ }^{3}$ \\ ${ }^{1}$ Syracuse University \\ ${ }^{2}$ University of Arkansas at Little Rock \\ ${ }^{3}$ Syracuse University
}

\section{Overview}

This paper provides a framework for examining what services are and will be required for consumers participating in the vast electronic market that is the Internet. There are many profound changes taking place, somewhat different than could be envisioned when Electronic Market Theory was first developed, but in general quite consistent with the theory $[1,2]$. From the perspective of the service provider the most important insights are that consumers have been empowered by the Web 2.0 technologies to provide or tailor the services that satisfy their needs, and that a key job of the service provider is to build the platforms that make the consumer's job as easy and transparent as possible. The chain of reasoning supporting this insight is summarized below and then elaborated on in the following sections:

- The technologies associated with Web 2.0 have been enabled by continued technology cost performance improvements and increased capabilities for coordination. This is observable since the 1970 s and will continue possibly at higher rates of cost performance improvements in the coming decade [3]

- There have been several significant and related effects of the improved coordination capabilities that can be observed on the Internet as consumer electronic markets continue to evolve. They are described in more detail in the balance of this paper.

- Applications are now able to support a much wider range of human emotions/needs than in the past. Successful applications have become platforms that in effect assist the user in defining which needs are of interest to them and how they want them to be satisfied.

- Electronic consumer markets have evolved from simple and easy to describe, low asset specific, tangible products, to complex, higher asset specific, intangible products, therefore extending the size and nature of the electronic market quite dramatically. 
- Everything the consumer does on the Internet is a market choice. Choosing Facebook or buying a book from Amazon are both market choices that must provide the revenue to enable the supplier to prosper.

The Internet has become a latent electronic market where the individual consumer creates the market space she is interested in by using facilitating software easily available on the Internet, including browsers, retrieval software and the like. Malone Yates and Benjamin [2] saw markets as moving from biased to unbiased to personalized. An example of the personalized market as the authors conceived it is typified by Amazon informing consumers that based on their last order they might be interested in a particular list of books. The concept of personalized markets has been greatly expanded by Web2.0 capabilities. To illustrate, many markets have become highly transparent (e.g., mortgages, interest rates, insurance) and many markets have become personalized by the consumer using the facilitating tools referred to above, as for example the markets to facilitate student loans [4].

\section{Technology Cost/Performance and the Cost of Coordination}

As technology cost performance driven by Moore's Law continues to unfold, it expands our capability to develop new and creative and often disruptive applications. Periodically such collections of technology through their ability to change coordination costs create vast new application potential and increase the ability of the technology to satisfy our human needs. Several examples illustrate this phenomenon:

- The increased capabilities in speed and storage capacity in the 1970s allowed PARC research to develop the Ethernet, the iconic desktop and other characteristics of today's workstation, thus precipitating the PC revolution [5].

- The improvements in computing power, telecommunications speed and reliability and large data bases made possible the emergence of electronic markets in the mid 1980s and subsequently the rapid exploitation of the Internet and Web browsers in the early to mid 1990s.

- The current bundle of Web 2.0 cost performance improvements have correspondingly enabled and made possible social networks, virtual worlds, and other Web 2.0 applications. It is the way in which these technologies are applied that allows us to satisfy a human need such as a sense of belonging in a social network. A fuller description of how human needs are satisfied through IT is developed later in the paper. 


\section{Web 2.0 and its Applications}

Web 2.0 and the applications derived from it have typically been explained by its underlying technologies per se rather than the impacts of the applications (e.g., Wigand, 2007). From our perspective Web 2.0's importance is that it has enabled web sites to more fully express and manifest human needs, therefore enlarging the electronic commerce application space.

Web 2.0, a phrase coined by O'Reilly Media in 2004, refers to a perceived or proposed second generation of Internet-based services - such as social networking sites, wikis, communication tools, and folksonomies - that emphasize online collaboration and sharing among users. Smith (2007) states that "...Web 2.0 is not just a set of technologies, but also attributes that have a social dimension: new business models, user-contributed content and user-generated metadata, more open and transparent business processes, simplicity in design and features, and decentralized and participatory products and processes" [6].

Representative technologies offering discrete functionalities associated with Web 2.0 are:

- AJAX (Asynchronous Javascript and XML) - hybrid of Javascript and XMLprovides dynamic, real-time, personalized services, increases speed, and flexibility.

- RSS (Really Simple Syndication) - provides live feeds from multiple sources, and personalized aggregation.

- Tagging - captures linkages, associate meanings/revealed family of interest structures, reveals untapped semantic structures associated with group interests. Sites such as Del.icio.us and Connotea allow users to organize information based upon user-generated tags.

- Wikis - collaborative authoring and editing, text-based, quick information sharing, as in the encyclopedia Wikipedia.

- Mashups - builds a composite integrated experience out of several related websites. Examples: Google Earth, ZIPskinny and comprehensive travel searches.

Two key attributes of these technologies are: 1) they are often used in different powerful compound applications such as tagging of wiki entries, social networking sites and the composite and integrated experience of mashups, and 2) users can easily add their content to the site using Web 2.0 technologies.

Figure 1 captures these interactions of technologies, and human needs in the context of electronic commerce from 1987 to today. It illustrates the progression of products amenable to electronic commerce from tangible commodity like products such as books to now highly intangible products such as information and social networks. 


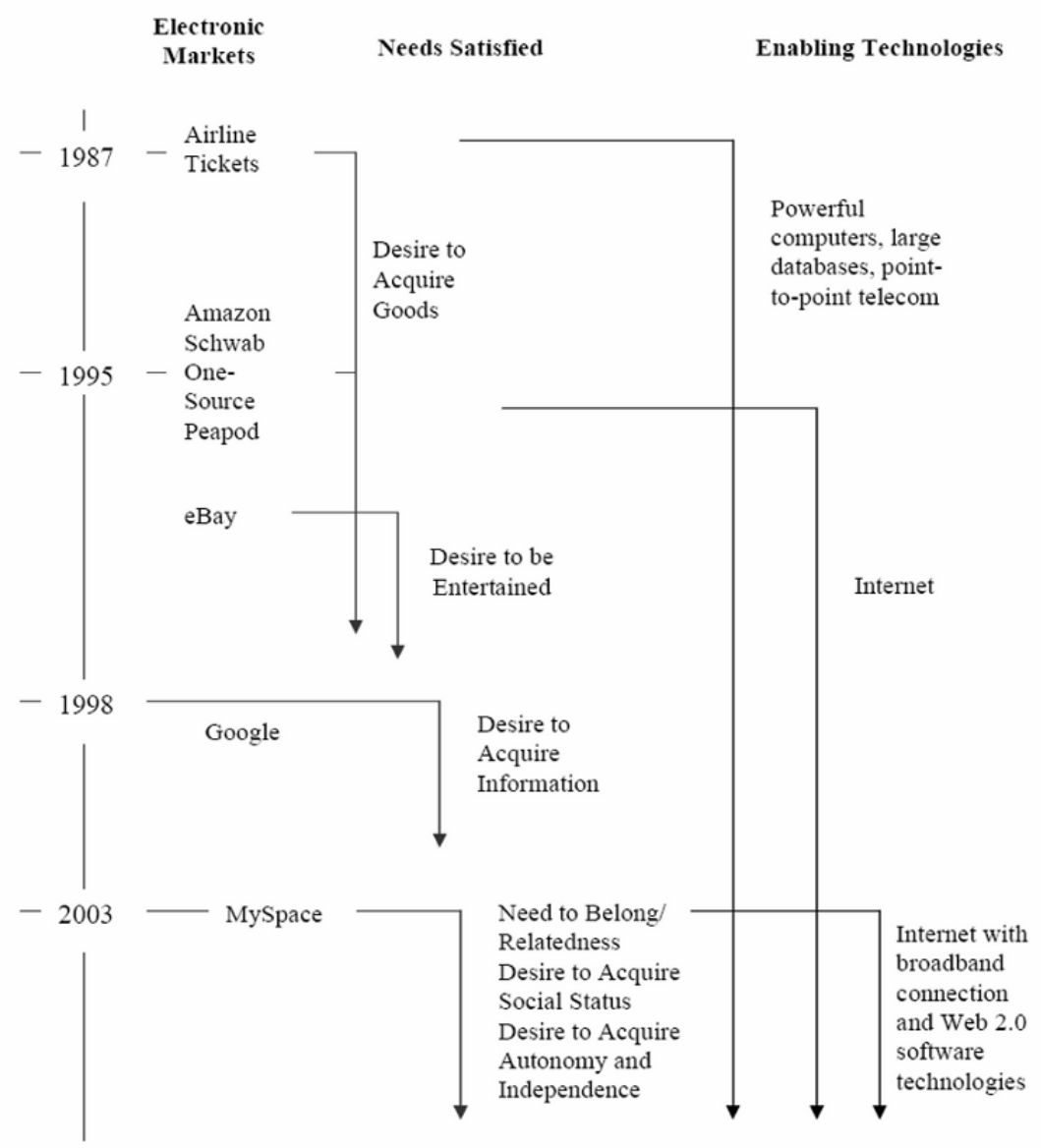

Fig. 1. Relationships between Technology Evolution, Ability To Express Human Needs and Forms of Consumer Electronic Commerce

The technology futurist or business strategist looking at this figure would be inclined to conclude that five years from now there will be sharper distinctions in human needs expressed and whole new classes of applications developed for the mass audience on the Internet. 


\section{Human Needs Satisfaction and the Internet}

All behavior may be viewed as being motivated by basic human needs. Over the past century, several models of human needs have been proposed, including Maslow's Hierarchy of Needs [7, 8], Self Determination Theory [9-11], and Motivation Theory [12-15]. In the majority of these cases, one model of basic needs has built upon the previous model.

Underlying human needs can be used to describe the behavior we observe on the Internet, and these basic principles of human behavior can be used to explain current trends and predict future trends. As a foundation for our present examination of human behavior, we are using a set of human needs derived from Maslow's classical hierarchy of needs.

Maslow's hierarchy describes five fundamental needs that motivate human behavior:

1. Physiological Needs: the needs for food and shelter.

2. Safety Needs: the need to feel safe from harm.

3. Belongingness Needs: the need to feel affection and to belong

4. Esteem Needs: the need to have a stable high evaluation of oneself, including needs for achievement, adequacy, confidence, independence, strength and also the need for reputation, importance, attention, appreciation, and recognition.

5. Self-actualization: the need for self-fulfillment.

For the majority of modern Western society, we suggest that the most basic physiological and safety needs are met. Therefore, these needs should be reinterpreted in the context in which we live. It follows that it is more likely for such users to use the web to meet our needs for belongingness, esteem, and selfactualization. Individuals in developing nations oftentimes face severe restrictions on what sites may be accessed on the Internet, due to governmental control, cultural norms, or infrastructural constraints [16]. Due to these restrictions, individuals in developing nations may be more inclined to use the web to satisfy more basic needs as well.

In addition to Maslow's five needs, we have added an additional basic need, the need for entertainment. Entertainment or play has not been adequately addressed in Maslow's hierarchy of needs, despite being a vital aspect of human behavior. Aside from the obvious desire and need to play by children, play and forms of play as in entertainment are also an important component of adult life. Examples, physical or virtual, are games, participation in sports, solving puzzles, etc. Clearly, this is an essential element observable on the Internet: entire websites and applications have been developed to fulfill this particular need. Some popular online games are played by millions of users worldwide and for some a play cycle may be more than nine months. In terms of revenue, the gaming industry is larger than Hollywood. When viewing these basic needs in relation to the Internet, Maslow's basic need structure can be adapted to describe several needs observable on the Internet. 
An example of human needs on the Internet applied to a social networking site follows below:

Table 1. MySpace as an Illustration Of Human Needs Satisfaction On The Internet

\begin{tabular}{|c|c|c|}
\hline MySpace & $\begin{array}{l}\text { Need to } \\
\text { Belong/Relatedness } \\
\text { Desire to Acquire Social } \\
\text { Status } \\
\text { Desire to Acquire } \\
\text { Autonomy and } \\
\text { Independence }\end{array}$ & $\begin{array}{l}\text { MySpace allows users to } \\
\text { befriend other users, } \\
\text { meet new people sharing } \\
\text { common interests, and } \\
\text { interacting with friends } \\
\text { through blogs and guest } \\
\text { books, fulfilling users' } \\
\text { need for belongingness } \\
\text { and relatedness. } \\
\text { Through their social } \\
\text { networks, users can also } \\
\text { acquire social status by } \\
\text { linking to more friends, } \\
\text { with many users linking } \\
\text { to hundreds of friends. } \\
\text { Users can also identify } \\
\text { their top friends (through } \\
\text { the "top eight" feature), } \\
\text { allowing a user to } \\
\text { essentially sort their } \\
\text { friends, indicating which } \\
\text { friends users hold } \\
\text { highest in esteem. } \\
\text { Moreover, MySpace } \\
\text { provides users with the } \\
\text { ability to customize their } \\
\text { profile page, including } \\
\text { backgrounds, music, and } \\
\text { pictures allowing users } \\
\text { to fulfill their need of } \\
\text { autonomy and } \\
\text { independence. }\end{array}$ \\
\hline
\end{tabular}

A more detailed description of human needs and the Internet in terms of popular sites is presented as an appendix to this paper. We understand that there are many ways of looking at human needs and the Internet, but we would like to suggest that what we present is a pointer to the kind of detailed analysis service providers will seek to satisfy, in order to achieve competitive positioning. 


\section{Surprises in the Evolution of Internet Consumer Markets}

Electronic market theory describes the attributes of tangible products that with increasing IT cost performance will be more and more conducive to market transactions rather than controlled through traditional hierarchical models of management. As evidence, e-commerce sales now account for a significant portion of overall retail spending, and are growing at a rate faster than retail sales in general. Sales of $\$ 108$ billion in 2006 topped those at electronics and appliance stores. And in the final quarter of 2006, online shopping accounted for $3 \%$ of total retail sales; nearly double the share at the end of 2002 [17]. According to the research firm Cowen \& Co., e-commerce retail sales are said to have climbed another $20 \%$, to $\$ 129$ billion, in 2007 . All of the above demonstrates a basic agreement with the principles of electronic market theory.

However a number of surprises have occurred in the consumer market evolution:

- As Figure 1 reveals there has been a shift from tangible products such as books to intangible products such as information and social networks.

- Personalized consumer specific markets on the Internet are for the most part formed not by market makers, but by the consumer using the facilitating tools of the Internet, browsers and retrieval programs such as Google to create the desired market space to search in. Thus a Google search on hearing aids produces a list of such devices and a product code sent to a specialized retrieval site such as Price Grabber provides a list of sites and prices for the hearing aid product. Market maker profits (as theory predicted) have been hard to find but much of their profits have gone to the owners of the facilitating tools such as Google. We note that there have been some very successful market makers, notably E-Bay who provides a market for a vast array of consumer products, and the brokerage firm Charles Schwab [1] who created the first and most successful market in mutual funds.

- Although the market for tangible products can be very large as exemplified by Amazon's current volume. They are tiny in size compared to the markets in intangible products such Google, MySpace and FaceBook. Creating the revenue base to provide the technical and administrative support these volumes require provides a significant level of risk to the newer class of intangible market choices. For example, how sticky will Facebook be as other and trendier social networks arrive, and will the social network users buy into the type of advertising model developed so successfully by Google. 


\section{Conclusions and Reflections for Service Providers}

In concluding this brief overview of how consumer electronic markets are changing let us first consider the key areas of immediate concern for those in the business of providing services.

- First and probably most significantly, service providers must realize that the consumer has been freed from the vendor as pusher of information. She can now use the Web2.0 technologies and be quite specific about what services are desired, as she creates her personalized market. Thus rather than providing a set of options, a platform that allows the consumer to develop her market of choice and its attributes becomes of primary importance.

- Second, understanding consumers and being able to help consumers differentiate the various human needs they want to satisfy becomes an important aspect of service.

- Third, the ability to create and maintain sticky sites that can deliver the advertising able to yield the revenues necessary for sustaining the volumes of consumer interactions we are now discovering on the information and social network sites becomes a major consideration.

- Finally, the service providers must recognize that technology cost performance will create new technology capabilities. We refer to them as Web 3.0 for convenience and suggest that these will allow more sophisticated expression of needs The challenge to keep up with the empowered consumer will get more and more challenging.

To summarize, services offered within the Web 2.0 framework are now part of the Internet's evolutionary history. In the short term, a firm that today wants to be active on the Internet, has no choice but to find its appropriate role via Web 2.0. Most major firms, including BMW, Google, IBM, and many others are aware of the issues presented above, and, are positioning themselves to find their strategic place, position and fit within these developments. They are also looking at the longer-term consequences.

- Providers of services on the Internet must recognize what may well be described as a shift in how we view the web. This shift forces service providers to take a new look at recognizing innovative opportunities and challenges that cross a number of dimensions, including media, the Web, organizations, economics, society and culture.

- Providers of services on the Internet must recognize the increased participation of the users on the web, who tend to interact to the content produced by other users, leading to increased participation in social networks. Users are able to debate on Weblogs and distribute information faster and more personalized via the RSS (Real Simple Syndication) format than via the classical media. Users leave MySpace and Facebook windows open all day to receive alerts: the average stay for MySpace users is 29 minutes and the average number of pages viewed is 75.6 . 
- Providers of services on the Internet must recognize that the trends we have examined are just one more iteration of capabilities. As the waves of IT cost performance inexorably continue, they will create new business opportunities. Thus user personalized applications can be expected in the living room and in the office alike, and will find parallel manifestations in the mobile communications area

- Providers of services on the Internet must recognize that these advances strongly suggest that firms have no choice but to keep in step with these developments. The challenges for firms and users will be to blend, merge and consolidate these into an integrated and comprehensive concept such that users enjoy a best possible experience while satisfying the widest range of human needs.

- Finally, providers of services on the Internet must find their way in dealing with several interrelated forces: 1) the rapid and enormous growth of social network products whose longevity and stickiness in the marketplace has yet to be proved as sustainable business models, 2) determining which pricing structures work best, and 3) and what users are willing to pay to fulfill their needs. These, as well as many other questions will have to be addressed by future research.

We hope that these contributions shed some light on how management and the academic world may view and understand these developments.

\section{Appendix}

Derivations of Human Needs Satisfaction on the Internet

Tables 2, 3 and 4 depict our perspectives, explanations and examples of human needs satisfaction on the Internet. The framework and examples chosen are to be seen as illustrative of our needs satisfaction perspective.

Table 2. Hierarchy of Needs Reflected on the WWW

\begin{tabular}{|c|c|}
\hline Maslow's Hierarchy of Needs & Corresponding Website Hierarchy \\
\hline \multirow[t]{2}{*}{ 1. Physiological Needs } & a. Desire to Acquire Goods \\
\hline & b. Desire to Acquire Information \\
\hline \multirow[t]{2}{*}{ 2. Safety Needs } & a. Desire to Acquire Goods \\
\hline & b. Desire to Acquire Information \\
\hline 3. Belongingness Needs & c. Need to Belong/Relatedness \\
\hline 4. Play/Entertainment Needs & d. Desire to be entertained, to be playful \\
\hline \multirow[t]{3}{*}{ 5. Esteem Needs } & e. Desire to Acquire Social Status \\
\hline & f. Desire to Acquire Power and Authority \\
\hline & g. Desire to Acquire Autonomy and Independence \\
\hline 6. Self-actualization Needs & $\begin{array}{l}\text { f. Desire to Acquire Power and Authority } \\
\text { g. Desire to Acquire Autonomy and Independence }\end{array}$ \\
\hline
\end{tabular}


Using a selection of human needs including those above, we can categorize popular websites and web services by the needs they meet and fulfill. For example, certain websites may help humans to fulfill their need to belong and relate to others, provide a means for their need to communicate within their chosen community, or help an individual to acquire forms of power and authority. Many webservices meet several such needs.

Here we choose to categorize several popular websites, including five social networking sites. The social networking websites included in our analysis were chosen based upon their relatively large number of users, i.e. MySpace, Hi5, Xanga, Classmates.com, and Orkut [18]. Several sites were chosen because they are representative examples of Web 2.0 functionalities. Others were chosen because they were historically interesting sites that were developed before Web 2.0 emerged (but have since developed Web 2.0 capabilities), while other sites were chosen because of their uniqueness and the possibility that they are indicators of future functionalities. As described, these sites were chosen to provide an interesting, illustrating and partially representative popular mix. Within this specific context they may be seen as representative, yet the authors openly admit that their choice represents a convenience sample.

We envision the WWW as a mirror-like reflection of real-life human (dyadic, group, organizational and societal) activities, in which these sites' respective functionalities appeal to basic needs of human nature. By examining that subset of activities on the WWW that entail business transactions, we realize that it is the challenge for business to find out how to best use the web while realizing that these developments must be embraced and incorporated judiciously and sensitively.

Table 3 depicts a representative sample of websites from our list with a detailed explanation of the needs met by that site's functionality. For clarity and simplicity, we have chosen to only assign a maximum of three needs to each website/web service listed below. Table 4 categorizes all websites by need and highlights characteristics of sites that help users to fulfill these needs. 
Table 3. Salient Examples of Websites Fulfilling Different Human Needs

\begin{tabular}{|c|c|c|}
\hline Website & Human Behavior Attribute(s) & Explanation of reasoning \\
\hline Amazon & $\begin{array}{l}\text { Desire to Acquire Goods } \\
\text { Desire to Acquire Information } \\
\text { Desire to Acquire Power and Authority }\end{array}$ & $\begin{array}{l}\text { Amazon allows users to acquire goods } \\
\text { (e.g., books, videos, and other items) } \\
\text { and acquire information about these } \\
\text { goods, including previews and } \\
\text { recommended titles (based upon other } \\
\text { users buying patterns). Additionally, } \\
\text { users can also obtain peer-created } \\
\text { information about the book through } \\
\text { others' reviews and ratings before } \\
\text { purchasing an item. By submitting } \\
\text { reviews, individuals can exert power } \\
\text { and authority that may influence users' } \\
\text { purchasing decisions. }\end{array}$ \\
\hline$\underline{\text { Del.icio.us }}$ & $\begin{array}{l}\text { Desire to Acquire Information } \\
\text { Desire to Acquire Power and Authority }\end{array}$ & $\begin{array}{l}\text { Del.icio.us allows users to tag and use } \\
\text { tags created by others in order to } \\
\text { facilitate finding and organizing } \\
\text { information on the web. Users can also } \\
\text { use tags to express themselves and } \\
\text { assert their knowledge for the purpose } \\
\text { of classifying a website. }\end{array}$ \\
\hline \multirow[t]{2}{*}{ MySpace } & $\begin{array}{l}\text { Need to Belong/Relatedness } \\
\text { Desire to Acquire Social Status } \\
\text { Desire to Acquire Autonomy and } \\
\text { Independence }\end{array}$ & $\begin{array}{l}\text { MySpace allows users to befriend other } \\
\text { users, meet new people sharing common } \\
\text { interests, and interacting with friends } \\
\text { through blogs and guest books, fulfilling } \\
\text { users' need for belongingness and } \\
\text { relatedness. }\end{array}$ \\
\hline & & $\begin{array}{l}\text { Through their social networks, users can } \\
\text { also acquire social status by linking to } \\
\text { more friends, with many users linking to } \\
\text { hundreds of friends. Users can also } \\
\text { identify their top friends (through the } \\
\text { "top eight" feature), allowing a user to } \\
\text { essentially sort their friends, indicating } \\
\text { which friends users hold highest in } \\
\text { esteem. Moreover, MySpace provides } \\
\text { users with the ability to customize their } \\
\text { profile page, including using } \\
\text { backgrounds, music, and pictures } \\
\text { allowing users to fulfill their need of } \\
\text { autonomy and independence. }\end{array}$ \\
\hline
\end{tabular}




\begin{tabular}{lll}
\hline Website & Human Behavior Attribute(s) & Explanation of reasoning \\
\hline SecondLife & Need to Belong/ Relatedness & SecondLife is unique as it serves as a \\
platform for many different activities. \\
Desire to Acquire Goods & SecondLife has been used as a place \\
Desire to Acquire Social Status & where users can meet others with \\
Desire to Acquire Autonomy and & similar interests, can acquire goods \\
Independence & using Linden dollars (which relate to \\
Desire to be Entertained & USD exchange rates), and can express \\
& themselves through things they build, \\
& create, or buy for their avatar. \\
& Additionally, goods acquired or built in \\
& SecondLife can help users to improve \\
& their social status, such as a user \\
& building a large mansion on his/her \\
& island. Users also often use SecondLife \\
& as a form of entertainment, much like a \\
& game. \\
& YouTube allows users to view clips of \\
YouTube & videos for entertainment purposes or \\
& view informative videos (such as how-to \\
Desire to be Entertained & videos). YouTube allows users to post \\
Desire to Acquire Autonomy and & their own self-created videos, \\
Independence & facilitating self-expression. \\
&
\end{tabular}

Table 4. Human Needs and Corresponding Exemplary Websites

\begin{tabular}{|c|c|c|}
\hline Human Need & Websites & Explanation \\
\hline a. Desire to Acquire Goods & $\begin{array}{l}\text { Amazon.com } \\
\text { Clipsyndicate.com } \\
\text { Craigslist } \\
\text { Ebay } \\
\text { Freecycle } \\
\text { Google } \\
\text { Napster } \\
\text { SecondLife }\end{array}$ & $\begin{array}{l}\text { These websites allow users to } \\
\text { acquire goods. E.g., } \\
\text { amazon.com allows users to } \\
\text { acquire goods including books, } \\
\text { movies, and music, while } \\
\text { Google's advertising allows } \\
\text { users to acquire goods related to } \\
\text { users' searches. }\end{array}$ \\
\hline $\begin{array}{l}\text { b. Desire to Acquire } \\
\text { Information }\end{array}$ & $\begin{array}{l}\text { Amazon.com } \\
\text { Craigslist } \\
\text { Del.icio.us } \\
\text { Freecycle } \\
\text { Google } \\
\text { Smallworld.net } \\
\text { Wikipedia } \\
\text { YouTube }\end{array}$ & $\begin{array}{l}\text { These websites allow users to } \\
\text { find or to organize information. } \\
\text { E.g., Amazon.com allows users } \\
\text { to read reviews and view } \\
\text { metadata on books and other } \\
\text { products; Del.icio.us allows } \\
\text { users to organize and search } \\
\text { information through tagging, } \\
\text { while Google allows users to } \\
\text { search information. }\end{array}$ \\
\hline
\end{tabular}




\begin{tabular}{|c|c|c|}
\hline$\underline{\text { Human Need }}$ & Websites & Explanation \\
\hline c. Need to Belong/ Relatedness & $\begin{array}{l}\text { MySpace } \\
\text { Hi5 } \\
\text { Xanga } \\
\text { Classmates.com } \\
\text { Orkut } \\
\text { SecondLife } \\
\text { Craigslist }\end{array}$ & $\begin{array}{l}\text { These websites allow users to } \\
\text { connect and link to others, meet } \\
\text { new people based upon shared } \\
\text { interests, and interact through } \\
\text { various features. E.g., MySpace } \\
\text { allows users to link their } \\
\text { profiles to other users' profiles, } \\
\text { Xanga allows users to create } \\
\text { blogrings of blogs on related } \\
\text { topics, and SecondLife allows } \\
\text { users to interact through real- } \\
\text { time chat and meeting spaces. }\end{array}$ \\
\hline $\begin{array}{l}\text { d. Desire to Acquire Social } \\
\text { Status }\end{array}$ & $\begin{array}{l}\text { MySpace } \\
\text { Hi5 } \\
\text { Xanga } \\
\text { Classmates.com } \\
\text { Orkut } \\
\text { SecondLife }\end{array}$ & $\begin{array}{l}\text { These websites allow a user to } \\
\text { acquire social status through the } \\
\text { number of connections to others } \\
\text { (such as the number of friends } \\
\text { their respective profile is } \\
\text { connected to) and the status of } \\
\text { the individuals they are } \\
\text { connected to, through ranking } \\
\text { or rating of others, or through } \\
\text { displays of virtual goods. E.g., } \\
\text { MySpace indicates how many } \\
\text { profiles/friends a person is } \\
\text { linked to and allows users to } \\
\text { indicate their top friends, Orkut } \\
\text { allows users to rate others on } \\
\text { "trust", "coolness" and } \\
\text { "sexiness," and SecondLife } \\
\text { allows users to acquire virtual } \\
\text { goods (such as clothing for } \\
\text { users' avatars) which may } \\
\text { increase users' social status. }\end{array}$ \\
\hline $\begin{array}{l}\text { e. Desire to Acquire Power and } \\
\text { Authority }\end{array}$ & $\begin{array}{l}\text { Amazon } \\
\text { Clipsyndicate.com Del.icio.us } \\
\text { Smallworld.net } \\
\text { Wikipedia } \\
\text { Youtube }\end{array}$ & $\begin{array}{l}\text { These websites allow users to } \\
\text { exert their power, opinion, } \\
\text { influence, control and authority } \\
\text { by serving as reviewers, rating } \\
\text { materials, or creating or } \\
\text { organizing information. E.g., } \\
\text { Wikipedia allows users to create } \\
\text { and review entries/information, } \\
\text { Del.icio.us allows the tagging } \\
\text { and organizing of information, } \\
\text { and Smallworld.net allows users } \\
\text { to rate restaurants and } \\
\text { destinations. }\end{array}$ \\
\hline
\end{tabular}




\begin{tabular}{|c|c|c|}
\hline Human Need & Websites & Explanation \\
\hline $\begin{array}{l}\text { f. Desire to Acquire Autonomy } \\
\text { and Independence }\end{array}$ & $\begin{array}{l}\text { SecondLife } \\
\text { SimCity } \\
\text { MySpace } \\
\text { Hi5 } \\
\text { Xanga } \\
\text { Classmates.com } \\
\text { Youtube } \\
\text { Facebook }\end{array}$ & $\begin{array}{l}\text { These websites allow users to } \\
\text { express themselves through } \\
\text { website features, such as } \\
\text { through designing or building } \\
\text { items or customizing features. } \\
\text { E.g., SecondLife allows uses to } \\
\text { express themselves through } \\
\text { their choice of avatar and } \\
\text { through building virtual objects, } \\
\text { while SimCity allows uses to } \\
\text { build and maintain a city. }\end{array}$ \\
\hline g. Desire to be entertained & $\begin{array}{l}\text { Ebay } \\
\text { Google } \\
\text { Napster } \\
\text { SecondLife } \\
\text { SimCity } \\
\text { YouTube }\end{array}$ & $\begin{array}{l}\text { These websites allow users to } \\
\text { be entertained. They provide } \\
\text { goods, information, or services } \\
\text { which users find entertaining. } \\
\text { E.g., SecondLife can be used as } \\
\text { an escape or game for } \\
\text { entertainment, YouTube allows } \\
\text { users to watch a wide array of } \\
\text { videos, Ebay allows users to } \\
\text { watch the excitement of an } \\
\text { online auction, and Google } \\
\text { allows users to surf the web and } \\
\text { be "entertained" by the list of } \\
\text { search results they find. }\end{array}$ \\
\hline
\end{tabular}

\section{References}

1. R. Benjamin and R. Wigand, "Electronic Markets and Virtual Value Chains on the Information Superhighway," Sloan Management Review, vol. 36, pp. 6272, 1995.

2. T. W. Malone, J. Yates, and R. I. Benjamin, "Electronic markets an electronic hierarchies," Communications of the ACM, vol. 30, pp. 484-497, 1987.

3. R. Kurzweil, Fine Living in Virtual Reality, in The Invisible Future: The Seamless Integration Of Technology Into Every Day Life: McGraw Hill, 2002.

4. E. Levenson, "How to Shop For Student Loans," in Fortune, 2008.

5. M. A. Hiltzik, Dealers of Lightning: Xerox PARC and the Dawn of the Computer Age. New York: Harper Collins, 1999.

6. D. M. Smith, "Web 2.0: Structuring the Discussion," Gartner Research October 31, 2007.

7. A. H. Maslow, Motivation and Personality. New York: Harper \& Row, 1970.

8. A. H. Maslow, "A Theory of Human Motivation," Psychological Review, vol. 50, pp. 370-396, 1943. 
9. E. L. Deci and R. M. Ryan, "The "what" and "why" of goal pursuits: Human needs and the self-determination of behavior," Psychological Inquiry, vol. 11, pp. 227-268, 2000.

10.R. M. Ryan and E. L. Deci, "Self-determination theory and the facilitation of intrinsic motivation, social development, and well-being," American Psychologist, vol. 55, pp. 68-78, 2000.

11.E. L. Deci, H. Eghrari, B. C. Patrick, and D. R. Leone, "Facilitating internalization: the self-determination theory perspective," Journal of Personality, vol. 62, pp. 119-142, March, 1994.

12.D. C. McClelland, Human motivation. New York: Cambridge University Press, 1987.

13.D. C. McClelland, Power: the inner experience. New York: Halstead, 1975.

14.D. C. McClelland, "Toward a theory of motive acquisition," American Psychologist, vol. 23, pp. 321-333, 1965.

15.D. C. McClelland, The achieving society. Princeton, N.J.: Van Nostrand, 1961.

16.M. L. Kaarst-Brown and J. R. Evaristo, "The Role of Culture in Global Electronic Commerce," in Global Information Technology and Electronic Commerce: Issues for the New Millennium Marietta, Georgia: Ivy League Publishing, 2002.

17.J. Mehring, "Cash Registers Are Ringing Online," in Business Week. vol. 24, 2007.

18.Wikipedia, "List of Social Networking Sites," 2007. 